\title{
Resilience to Stress and Disturbance, and Resistance to Bromus tectorum L. Invasion in Cold Desert Shrublands of Western North America
}

\author{
Jeanne C. Chambers, ${ }^{1 *}$ Bethany A. Bradley, ${ }^{2}$ Cynthia S. Brown, ${ }^{3}$ \\ Carla D'Antonio, ${ }^{4}$ Matthew J. Germino, ${ }^{5}$ James B. Grace, ${ }^{6}$ \\ Stuart P. Hardegree, ${ }^{7}$ Richard F. Miller, ${ }^{8}$ and David A. Pyke ${ }^{9}$
}

\begin{abstract}
${ }^{1}$ US Forest Service, Rocky Mountain Research Station, Reno, Nevada 89512, USA; ${ }^{2}$ Department of Natural Resources Conservation, University of Massachusetts, Amherst, Massachusetts 01003, USA $;{ }^{3}$ Department of Bioagricultural Sciences and Pest Management, Colorado State University, Fort Collins, Colorado 80523, USA; ${ }^{4}$ Department of Ecology, Evolution and Marine Biology, University of California, Santa Barbara, Santa Barbara, California 93106, USA; ${ }^{5}$ US Geological Survey, Forest and Rangeland Ecosystem Science Center, Boise, Idaho 83706, USA; ${ }^{6}$ US Geological Survey, National Wetlands Research Center, Lafayette, Louisiana 70506, USA;

${ }^{7}$ USDA Agricultural Research Service, Northwest Research Center, Boise, Idaho 83712, USA; ${ }^{8}$ Department of Range Ecology and Management, Oregon State University, Corvallis, Oregon 97331, USA; ${ }^{9}$ US Geological Survey, Forest and Rangeland Ecosystem Science Center, Corvallis, Oregon 97331, USA
\end{abstract}

\begin{abstract}
Alien grass invasions in arid and semi-arid ecosystems are resulting in grass-fire cycles and ecosystem-level transformations that severely diminish ecosystem services. Our capacity to address the rapid and complex changes occurring in these ecosystems can be enhanced by developing an understanding of the environmental factors and ecosystem attributes that determine resilience of native ecosystems to stress and disturbance, and
\end{abstract}

Received 21 December 2012; accepted 23 September 2013

Author Contributions: JCC, JBG and RFM conceived the paper and contributed text and figures; $\mathrm{BAB}$ contributed text and figures; $\mathrm{CB}, \mathrm{CD}$, MJG, SPH, and DAP contributed text; JCC wrote the manuscript.

*Corresponding author; e-mail: jchambers@fs.fed.us resistance to invasion. Cold desert shrublands occur over strong environmental gradients and exhibit significant differences in resilience and resistance. They provide an excellent opportunity to increase our understanding of these concepts. Herein, we examine a series of linked questions about (a) ecosystem attributes that determine resilience and resistance along environmental gradients, (b) effects of disturbances like livestock grazing and altered fire regimes and of stressors like rapid climate change, rising $\mathrm{CO}_{2}$, and $\mathrm{N}$ deposition on resilience and resistance, and (c) interacting effects of resilience and resistance on ecosystems with different environmental conditions. We conclude by providing strategies for the use of resilience and resistance concepts in a management context. At ecological site scales, state and transition models are used to illustrate how differences in resilience and resistance influence potential alternative vegetation states, transitions among states, and thresholds. At landscape scales management 
strategies based on resilience and resistance-protection, prevention, restoration, and monitoring and adaptive management-are used to determine priority management areas and appropriate actions.
Key words: environmental gradients; ecosystem productivity; plant traits; altered fire regimes; cheatgrass; fundamental and realized niche; management strategies; state and transition models.

\section{INTRODUCTION}

Alien grass invasions are resulting in ecosystemlevel transformations of entire landscapes in arid and semi-arid ecosystems worldwide ( $\mathrm{D}^{\prime}$ Antonio and Vitousek 1992). Such a transformation is currently occurring in cold desert shrublands of the western United States. These ecosystems are characterized by cold-wet winters and hot-dry summers and are ideally suited to annual grasses introduced from Eurasia, like cheatgrass (Bromus tectorum L.) (Knapp 1996). Cheatgrass is a highly plastic winter annual that is able to germinate in fall, winter, or spring. Rapid growth and high reproductive capacity allow it to effectively compete with native species for early growing season moisture. The fine fuels that it contributes to these ecosystems promote fire spread, and can result in grass-fire cycles that provide positive feedbacks for its continued invasion (Brooks and others 2004). Conversion of native cold desert shrublands to annual grass dominance can change soil physical and chemical properties, decrease soil stability, and alter ecosystem processes like nutrient cycling and soil water flux and storage (Wilcox and others 2012). Areas invaded by cheatgrass and other annuals have increased fire risk and greatly diminished ecosystem services (Balch and others 2012).

In many cases initial invasion is facilitated by land uses or management activities that disturb native vegetation, increase resource availability, and promote establishment and spread (Chambers and Wisdom 2009). In the cold desert, historic land uses primarily include agriculture, mining and grazing by livestock (cattle, sheep, and horses). However, in recent decades, rapid population growth has resulted in new disturbances related to urban and energy development, energy and transportation corridors, and recreational activities. All these factors are taking place in the context of climate change, rising atmospheric $\mathrm{CO}_{2}$, and nitrogen $(\mathrm{N})$ deposition. Since the late 1800s when intensive land use began and cheatgrass was introduced, the cold desert sagebrush ecosystem declined from 25 to 13 million ha (Miller and others 2011), and cheatgrass came to dominate as much as 4 million ha in the states of Nevada and Utah alone (Bradley and others 2009). Many cold desert shrublands are fragmented and degraded, and many species associated with these ecosystems are of conservation concern, including the greater sage-grouse (Centrocerus urophasianus) whose status warrants listing under the United States Endangered Species Act (US Department of Interior 2010).

Our capacity to address the rapid and complex changes occurring in cold deserts can be enhanced by developing an understanding of the environmental factors and ecosystem attributes that determine resilience of native ecosystems to stress and disturbance, and resistance to invasion (Brooks and Chambers 2011) (see Table 1 for definitions). Cold desert shrublands provide an excellent opportunity to increase our understanding of these concepts and their use in a management context. They include strong environmental gradients and exhibit significant differences in resilience and resistance (Figure 1; Brooks and Chambers 2011; Miller and others 2013; Chambers and others unpublished). Also, the individual stresses and disturbances affecting these ecosystems are relatively well-studied (for reviews see, Chambers and Wisdom 2009; Knick and Connelly 2011) as are the environmental factors and ecosystem attributes influencing the potential versus actual distribution (that is, fundamental vs. realized niche) of the primary invader, cheatgrass (for example, Chambers and others 2007; Monaco and Sheley 2012). Herein, we examine a series of linked questions to examine (a) environmental factors and ecosystem attributes that determine resilience and resistance to invasion across large landscapes, (b) effects of stress and disturbance on resilience and resistance, and (c) interactions between resilience and resistance. We conclude by providing strategies for the use of resilience and resistance concepts in a management context. At ecological site scales, state, and transition models are used to illustrate how differences in resilience and resistance influence potential alternative vegetation states, transitions among states, and thresholds. At landscape scales, management strategies based on resilience and resistance-protection, prevention, restoration, and monitoring and adaptive management-are used to determine priority management areas and 
appropriate actions. Although our focus is on cheatgrass invasion in cold desert shrublands of the western United States, we believe that the defini- tions and concepts in this paper have applicability to other ecosystems, particularly those experiencing annual grass invasions.

Table 1. Definitions of Terms Used in This Paper

Fundamental niche

The subset of $n$-dimensional environmental space of all possible conditions in which a species can maintain itself in the absence of competition, facilitation and other species interactions. The fundamental niche of an invading species determines the broadest extents of its potential distribution on the landscape (Hutchinson 1958)

Historical range of variability

Range of variability in disturbances, stressors, and ecosystem attributes that allows for maintenance of ecosystem resilience and resistance and that can be used to provide management targets (modified from Jackson 2006)

Realized niche

A subset of the fundamental niche that is determined largely by species interactions. The realized niche determines the actual distribution of an invading species on the landscape (Hutchinson 1958)

Resilience

Capacity of an ecosystem to regain its fundamental structure, processes and functioning when altered by stresses like increased $\mathrm{CO}_{2}$, nitrogen deposition, and drought and to disturbances like land development and fire (Allen and others 2005; Holling 1973)

Resistance

Capacity of an ecosystem to retain its fundamental structure, processes and functioning (or remain largely unchanged) despite stresses, disturbances or invasive species (Folke and others 2004)

Resistance to Invasion

Abiotic and biotic attributes and ecological processes of an ecosystem that limit the population growth of an invading species (D'Antonio and Thomsen 2004)

Thresholds

Boundaries in conditions leading to alternative stable states. Thresholds are crossed when an ecosystem does not return to the original state via self-organizing processes after stress or disturbance and transitions to a new alternative state that is adjusted to the altered attributes or processes (Beisner and others 2003; Stringham and others 2003)

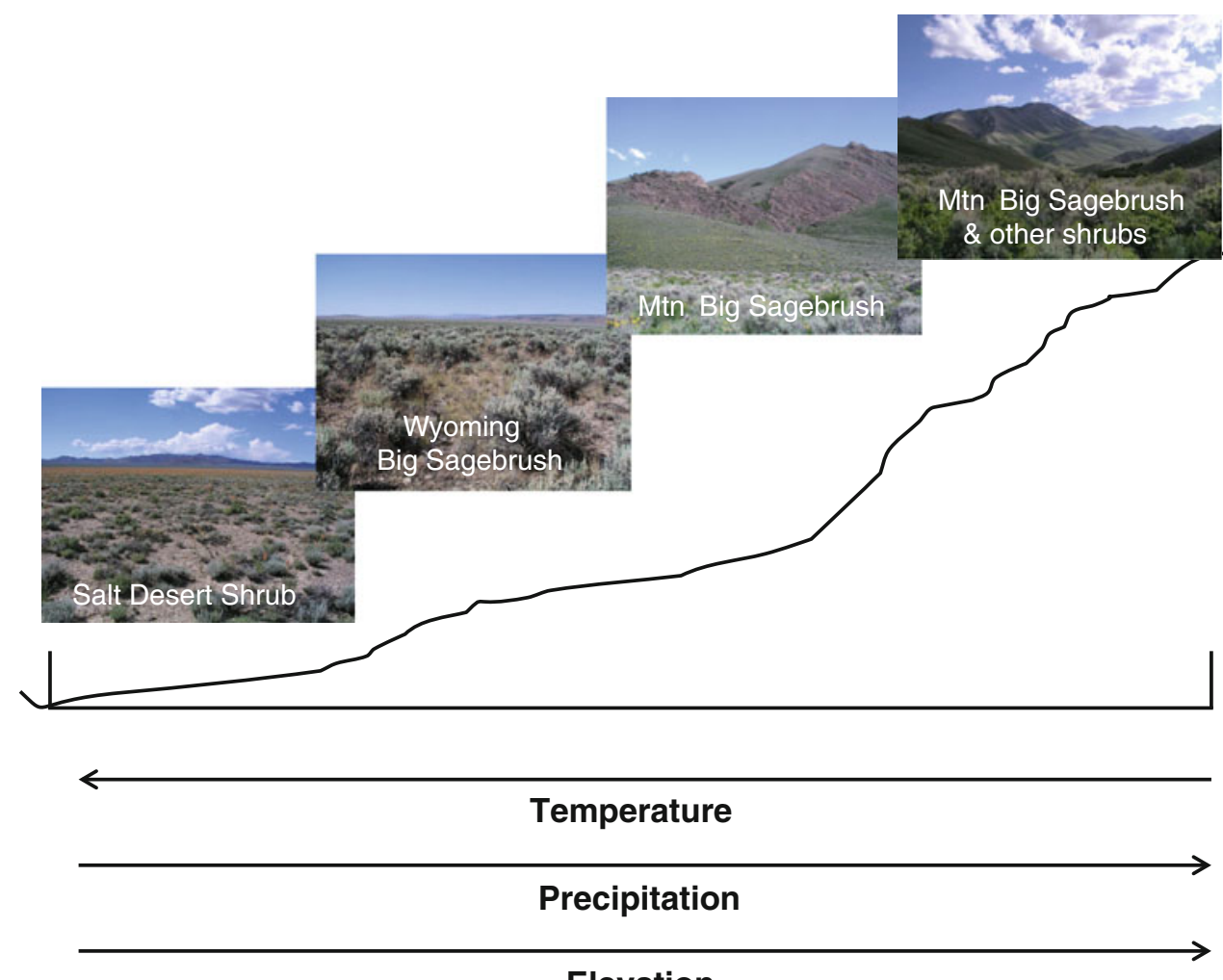

Elevation
Figure 1. The dominant vegetation types that occur along environmental gradients in cold desert shrublands of the western US. 


\section{How are Environmental Factors and ECOSystem Attributes Related to RESILIENCE TO DisturbanCE AND Resistance to InVASION?}

The environmental factors and ecosystem attributes that determine resilience of native ecosystems to stress and disturbance, and resistance to invasion can be illustrated with a simple conceptual model (Figure 2). The model shows that environmental factors, including climate, topography, and soils determine the abiotic and biotic attributes of ecosystems. Disturbance and stress, invasive species, and other global change factors act on the abiotic and biotic attributes of an ecosystem and influence its relative resilience and resistance over time. This model is consistent with that suggested for evaluating ecosystem sustainability (Chapin and others 1996). It also encompasses both the environmental factors and ecosystem attributes used to develop the ecological site descriptions and state and transition models that are increasingly used by managers in cold desert shrublands to evaluate management options (see Stringham and others 2003; Briske and others 2005; USDA Natural Resources Conservation Service 2013).

\section{Resilience to Stress and Disturbance}

In cold desert shrublands, resilience of native ecosystems to stress and disturbance changes along climatic and topographic gradients. Specifically, higher resilience has been shown to be associated with greater resource availability and more favorable environmental conditions for plant growth and reproduction (Figure 3A) (Condon and others 2011; Davies and others 2012). In the topographically diverse cold desert, environmental conditions range from hot and dry at the lowest elevations (salt desert shrub) to cold and moist at the highest elevations (mountain big sagebrush and other shrubs). Predictable differences exist in total resources, resource availability, and net annual primary productivity along these gradients (West 1983a, b; Smith and Nowak 1990). Higher precipitation and cooler temperatures coupled with greater soil development and plant productivity at mid to high elevations can result in greater nutrient and water availability than at low elevations (Alexander and others 1993; Dahlgren and others 1997). In contrast, minimal precipitation and high temperatures at low elevations result in poor soil development and lower resource availability for plant growth (West 1983a, b; Smith and Nowak 1990). These relationships also are observed at plant community scales where aspect, slope, and topographic position affect solar radiation, erosion processes, effective precipitation, soil development and, thus, vegetation composition and structure (Condon and others 2011; Johnson and Miller 2006). Cold desert ecosystems characterized by harsh environments and low productivity tend to

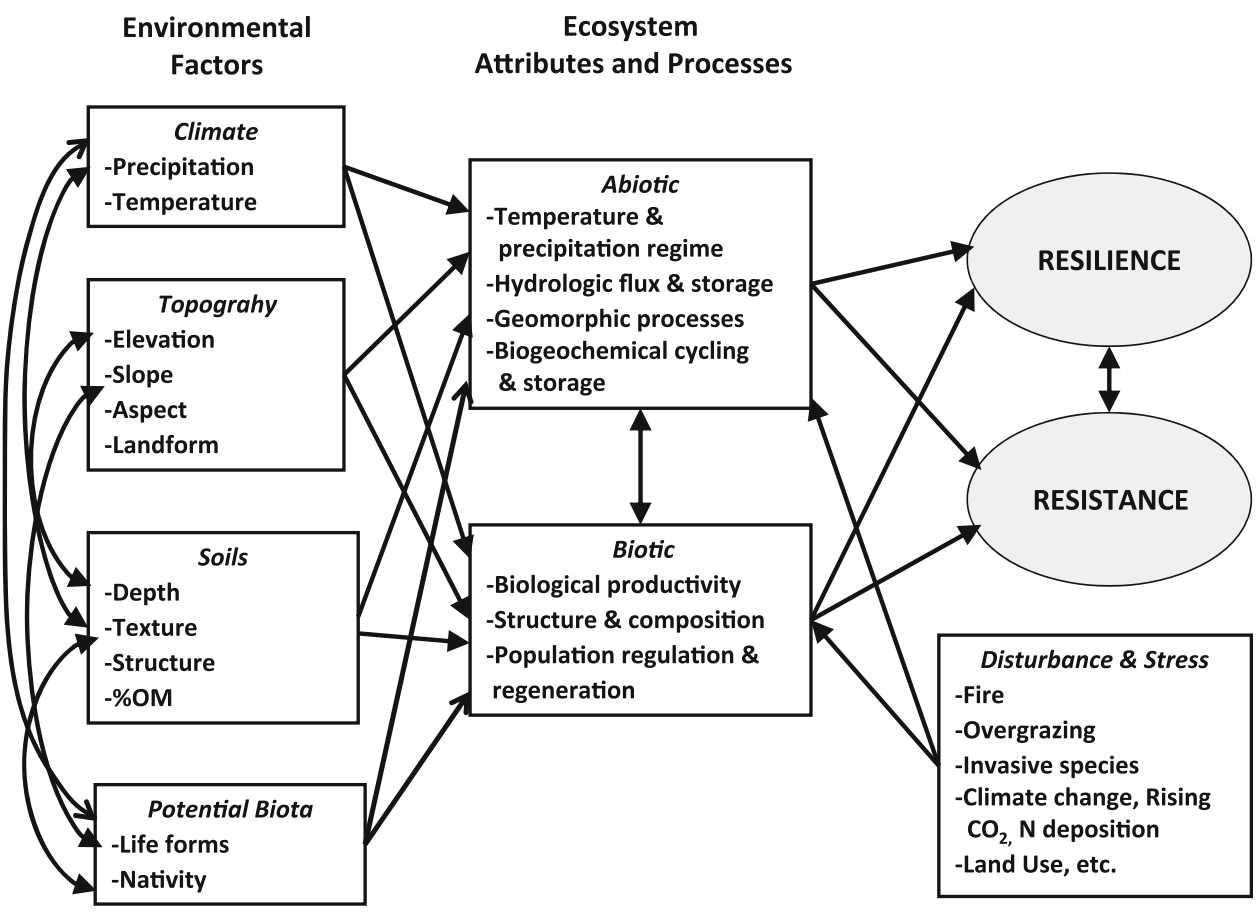

Figure 2. Conceptual model of the environmental factors and ecosystem attributes and processes that influence resilience and resistance. Disturbances and stresses can negatively affect ecosystem attributes and processes and, consequently, resilience, and resistance. 
exhibit lower resilience to disturbances of similar severity than more environmentally moderate ecosystems.

Specific adaptations to historical disturbances, coupled with higher productivity, can equate to greater ecosystem resilience to specific types of disturbance (Davies and others 2007). In cold desert shrublands, the historical role of fire and thus species adaptations to fire differ along environmental gradients. Ecosystems with relatively high productivity had more frequent pre-settlement fires due to high fuel abundance and continuity (Miller and others 2011), and typically have more fire tolerant species (Davies and others 2012). In contrast, lower elevation ecosystems tended to have smaller and less frequent fires due to limited fuel production and continuity (West 1983a). Many of the species that characterize salt desert ecosystems evolved in the near-absence of fire and are fire intolerant (Brooks and Minnich 2006). Similar relationships exist between fire frequency
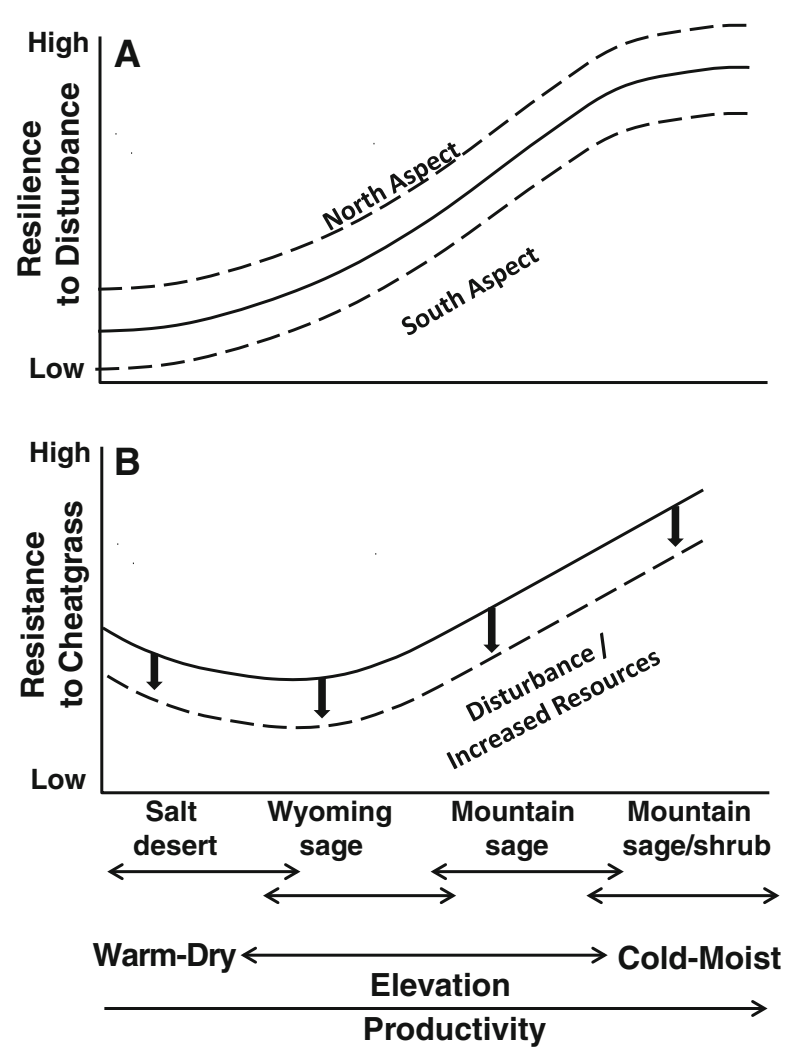

Figure 3. A Resilience to disturbance and stress along an environmental gradient in cold desert shrublands. Resilience varies as a function of topography. B Resistance to cheatgrass along an environmental gradient in cold desert shrublands. Resistance decreases as a result of disturbances and increases in resource availability (as indicated by the downward arrows). and fire tolerant life forms in semi-arid Mediterranean shrublands of southeast Australia (Pausas and Bradstock 2007). In both ecosystems, the trend is for increases in resprouting species and decreases in obligate seeders along environmental/productivity gradients (Davies and others 2012; Pausas and Bradstock 2007).

Resilience can be quantified by the amount of time it takes to return to the initial condition (sensu "engineering resilience") and/or the magnitude of change in ecosystem attributes (sensu "ecological resilience") following stress or disturbance (Peterson and others 1998). The influence of plant traits and environmental gradients on ecosystem resilience can be illustrated from prescribed fire research in cold desert shrublands exhibiting piñon and juniper encroachment (Chambers 2005). This research showed that prior to burning, mean biomass of perennial grasses and forbs increased over an elevation gradient characterized by Wyoming big sagebrush $(2103 \mathrm{~m})$, mountain big sagebrush $(2225 \mathrm{~m})$, and mountain big sagebrush/shrub $(2347 \mathrm{~m})$ (see Figure 1). Also, higher elevation sites had a greater proportion of rhizomatous and root-sprouting species. All sites were burned in prescribed fires in spring 2002. Three years after burning, all sites exhibited an increase in biomass of perennial herbaceous species. However, higher biomass of perennial grasses and forbs coupled with more fire tolerant shrubs at higher elevations resulted in a smaller initial change in community composition and more rapid recovery.

\section{Resistance to Invasion}

Resistance to invasive annual grasses depends on the environmental factors and ecosystem attributes that affect their fundamental and realized niches. The fundamental niche is a function of a species physiological and life history requirements for establishment, growth, and reproduction and, in cold desert shrublands, is determined primarily by temperature and precipitation regimes. In these ecosystems, germination, growth, and/or reproduction of cheatgrass is limited at low elevations by low and sporadic precipitation, constrained at high elevations by low soil temperatures, and optimal at mid elevations under relatively moderate temperature and water availability (Figure 3B; Chambers and others 2007; Meyer and others 2001). Slope, aspect, and soil characteristics modify soil temperature and water availability and determine expression of the fundamental niche of cheatgrass at landscape to plant community scales (Chambers and others 2007; Condon and others 2011; Reisner and others 2013). 
High variability in precipitation and growing season conditions affect expression of the fundamental niche over time. Cheatgrass exhibits strong inter-annual variability in growth that is closely related to annual precipitation (West and Yorks 2002; Bradley and Mustard 2005). Years with favorable environmental conditions can result in establishment of cheatgrass in marginal environments like salt deserts, but longer-term persistence requires either the necessary environmental conditions to maintain viable populations or high propagule pressure (Meyer and others 2001). Genetic variation in cheatgrass results in phenotypic traits that increase survival and persistence in populations from a range of environments that is likely contributing to the recent range expansion of this highly inbreeding species into marginal habitats (Merrill and others 2012; Ramakrishnan and others 2006).

The realized niche of invasive annual grasses is strongly mediated by resource availability and interactions with the native plant community (Figure 3B). In cold desert ecosystems, most plant growth occurs in spring and early summer when soil temperatures and water availability are favorable (Smith and Nowak 1990; Leffler and Ryel 2012). Rooting depth and access to deeper soil water increases in order from cheatgrass to perennial grasses to shrubs and trees (Dobrowolski and others 1990; Ryel and others 2010). However, cheatgrass as well as native grasses, shrubs, and trees all have shallow roots and use near-surface $(<0.5 \mathrm{~m})$ soil water during the spring/early summer growth period. Nutrient concentrations are highest in these shallow soils during this period and soil water potentials are sufficient for nutrient diffusion and plant uptake only prior to soil water depletion later in summer (Ryel and others 2010; Leffler and Ryel 2012). Differences among life forms and life stages in the timing and amount of resource uptake and use of shallow versus deep soil water affect species interactions and resistance to invasion (Booth and others 2003; Prevey and others 2010).

Cheatgrass, a facultative winter annual, typically germinates earlier (in the fall and under colderwinter temperatures), exhibits greater root elongation at low soil temperatures, and has higher nutrient uptake and growth rates than native species (James and others 2011; Knapp 1996). Seedlings of native perennial species are generally poor competitors with cheatgrass, but adults of native, perennial herbaceous species, especially those with similar growth forms and phenology, can be highly effective competitors (Booth and others 2003;
Chambers and others 2007; Blank and Morgan 2012). Disturbances or management treatments that reduce the abundance of perennial herbaceous species, shrubs, or trees can increase resource availability and expand the realized niche of cheatgrass given climate suitability and a propagule supply. Also, pronounced fluctuations in resources may decrease resistance of ecosystems whose species lack the capacity to fully utilize resource fluctuations (Rejmanek 1989; Davis and others 2000) as was observed in salt desert ecosystems during a series of high precipitation years in the 1980s (Meyer and others 2001). Longer-term outcomes typically depend on the relative abundance of native, perennial herbaceous species (Anderson and Inouye 2001; Chambers and others 2007).

\section{How do Stress and Disturbance INFLUENCE Resilience AND Resistance?}

Resilience of contemporary ecosystems is related to the type, characteristics, and historical range of variability of stress and disturbance (Jackson 2006). Disturbances like overgrazing by livestock, altered fire regimes, and stressors such as rapid climate change, rising $\mathrm{CO}_{2}$, and nitrogen deposition are typically outside of the historical range of variability and can reduce the resilience of native ecosystems. Loss of resilience is indicated by changes in environmental factors like temperature regimes, abiotic ecosystem attributes like water and nutrient availability and geomorphic processes, and biotic attributes such as vegetation structure and composition, biological productivity, and population regeneration (Figure 2; Chapin and others 1996). Resistance to invasive species can change when changes in abiotic and biotic attributes result in increased resource availability or altered habitat suitability that influence the fundamental or realized niche (Figure 4). Progressive losses of ecosystem resilience and resistance can result in abiotic and biotic thresholds beyond which the system cannot recover to the original state (Beisner and others 2003; Seastedt and others 2008).

\section{Livestock Grazing and Fire}

Fire and inappropriate grazing (timing, duration, and/or intensity) of livestock and other exotic herbivores are the most common disturbances associated with decreased resilience and resistance in cold desert ecosystems (D'Antonio and Vitousek 1992; Knapp 1996). Inappropriate grazing can decrease the relative abundance of palatable 


\section{A Fundamental vs Realized Niche of Cheatgrass}

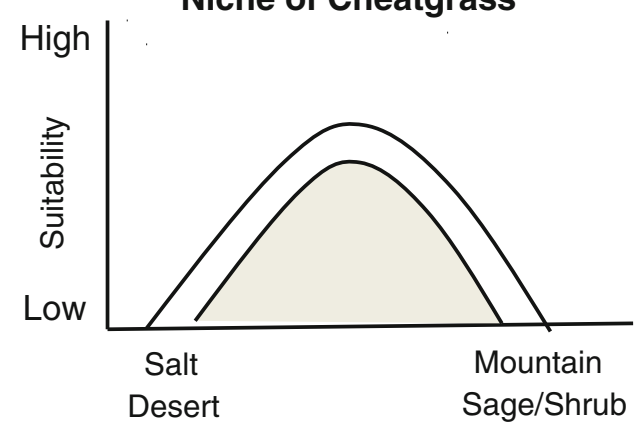

C Increased Temperatures

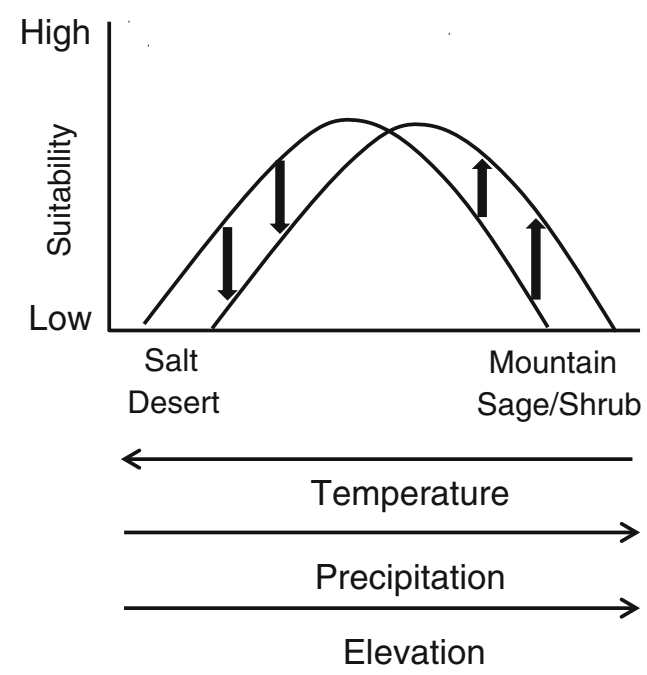

B Increased Resources

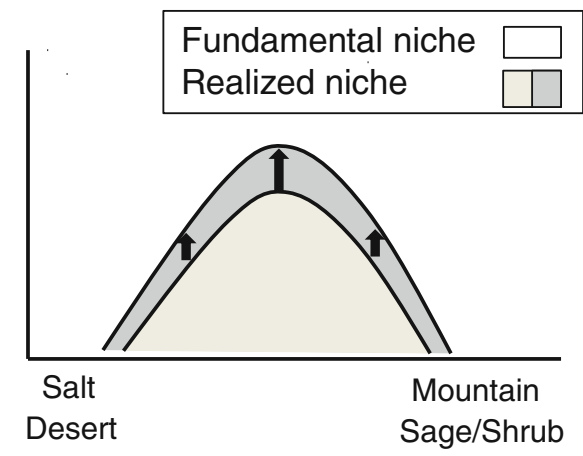

D Rising $\mathrm{CO}_{2}$

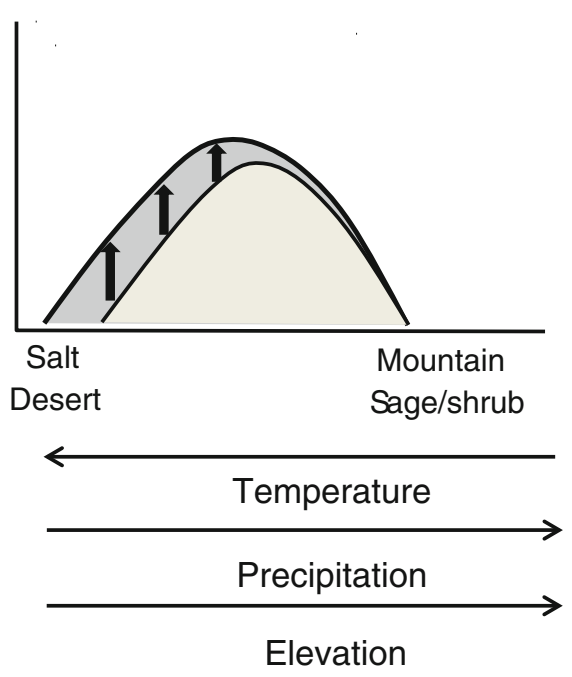

Figure 4. Some hypothetical but likely niche relations of cheatgrass over environmental gradients in cold desert shrublands. A The realized niche (gray) is a subset of the fundamental niche (white). B The realized niche may increases in response to disturbances and stresses that increase resource availability (dark gray). C The fundamental niche may shift if the climate becomes less suitable at lower elevations and more suitable at higher elevations. D The realized niche may increase at lower elevations due to rising $\mathrm{CO}_{2}$ and more favorable water relations (dark gray), but will not change at higher elevations due to temperature constraints. grasses and forbs, disrupt biological soil crusts, and increase soil surface disturbance in communities dominated by herbaceous species and shrubs/trees (Belnap 1995; Knapp 1996). These changes can increase available soil water and nitrate in the upper profile of cold desert soils (Leffler and Ryel 2012). Reduced competition due to removal of perennial herbaceous species by grazing coupled with higher resource availability can result in an increase in woody species and, thus, woody fuel loads (Miller and others 2011). With increasing levels of grazing intensity, bare soil can increase and cheatgrass can become progressively more abundant in interspaces among residual perennial herbaceous species (Reisner and others 2013). These changes can lower resilience to fire due to higher or more contiguous fine fuels that result in greater fire severity and extent and high mortality of fire-intolerant trees and shrubs. In the absence of perennial herbaceous species that can respond positively to fire and facilitate recovery, the den- sity, biomass, and seed production and, thus, realized niche of cheatgrass can increase in both salt desert (Beckstead and Augspurger 2004) and sagebrush ecosystems (Chambers and others 2007). Sagebrush ecosystems exhibit high variability in environmental attributes, and those located on coarser soils or characterized by higher heat loads are least resilient to grazing and resistant to cheatgrass (Reisner and others 2013).

Fires that remove woody species and other fireintolerant plants can increase resource availability and the realized niche of cheatgrass, but longerterm effects depend on the relative abundance of perennial herbaceous species and their capacity to compete for available resources. Increases in nutrient availability after fire occur due to deposition of ash onto the soil surface, release of $\mathrm{N}$ and phosphorus (P) from organic matter, and decomposition of belowground biomass (Neary and others 1999). Soil nutrients are inherently low in cold desert ecosystems, but available $\mathrm{N}\left(\mathrm{NO}_{3}{ }^{-}\right.$and 
$\mathrm{NH}_{4}{ }^{+}$) can increase up to 12 -fold after fire (Blank and others 1996) and remain elevated in surface soil layers for several years (Stubbs and Pyke 2005). Effects of fire on soil water are less predictable. Following fires that remove vegetation and litter, soil water near the soil surface is typically lower early in the growing season due to desiccation caused by wind and lack of shading (Chambers and Linnerooth 2001). After plant regrowth begins, soil water is often higher deeper in the soil profile on burned versus unburned areas due to removal of deeper-rooted, fire-intolerant shrubs (Chambers and Linnerooth 2001; Wilcox and others 2012). In resilient post-fire communities with abundant firetolerant perennial herbaceous species and/or shrubs, the increase in resources typically is used by resprouting herbs and shrubs (Chambers and others 2007). However, in post-fire communities with low abundances of these species, reduced competition and higher resource availability results in increased biomass and seed production of cheatgrass. Cheatgrass biomass and seed production can increase 2-3-fold after herbaceous species removal, 2-6-fold after fire, but 10-30-fold after removal plus fire in big sagebrush ecosystems (Chambers and others 2007).

\section{Climate Change, Rising $\mathrm{CO}_{2}$, and $\mathrm{N}$ Deposition}

Climate change has the potential to reduce resilience and resistance of native ecosystems through a decrease in climate suitability of individual species, changes in species interactions, and formation of novel communities (Williams and Jackson 2007). Down-scaled multi-model projections for cold desert shrublands show an increase in mean temperature of $2.5-3^{\circ} \mathrm{C}$ and a decrease in number of days when overnight temperatures drop below freezing by mid-21st century (2046-2065) (Abatzoglou and Kolden 2011). Projections for precipitation show considerable spatial heterogeneity, but strong agreement exists among models for a latitudinal dipole at about $37^{\circ} \mathrm{N}$ in which coolseason (Nov-Mar) precipitation decreases to the south and increases to the north (Abatzoglou and Kolden 2011). Increases in temperatures and elevation and latitudinal shifts in frost lines are predicted to cause species distributions to move upward in elevation and to more northern latitudes. Higher evapotranspiration rates and an increase in the magnitude and severity of droughts are predicted to limit species distributions at lower elevations and in southern portions of the cold desert due to decreased soil water availability
(Seager and others 2007). Lower elevations may no longer support persistent populations of cheatgrass, but higher elevations may become climatically more suitable and less resistant to invasion (Figure 3C; Bradley and others 2009). Also, climate suitability of cheatgrass may increase with less summer precipitation, but may be reduced with more summer precipitation (Bradley and others 2009).

Rising $\mathrm{CO}_{2}$ has the potential to alter resilience and resistance, but effects are likely to differ among ecosystem types. Since industrialization, atmospheric $\mathrm{CO}_{2}$ has risen from $280 \mathrm{ppm}$ in 1860 to about 400 ppm in 2013 (US Department of Commerce, NOAA 2012). Elevated $\mathrm{CO}_{2}$ increases water use efficiency of plants, and may result in slower rates of water depletion, improved plant water relations, and greater biomass production (Polley and others 2011). Biomass enhancement by elevated $\mathrm{CO}_{2}$ generally increases as growing season precipitation decreases, but is most pronounced in arid and semiarid ecosystems when other key resources, like water and $\mathrm{N}$, are not limiting (Nowak and others 2004). These biomass increases are often greatest in invasive annual grasses like cheatgrass and red brome (Bromus rubens), but are still significant in native perennial grasses and shrubs (Nowak and others 2004) including those in cold deserts (Smith and others 1987). Considerable differences exist among ecosystems in biomass enhancement due to differences in ecosystem attributes, plant physiological and morphological traits, and species interactions. In cold desert shrublands with relatively high resilience and resistance, rising $\mathrm{CO}_{2}$ may increase the competitive ability of shrubs and trees if higher water use efficiency causes an increase in deeper soil water due to slower rates of water depletion (Polley and others 2011). However, rising $\mathrm{CO}_{2}$ also may increase water use efficiency and competitive ability of perennial grasses. Thus, rising $\mathrm{CO}_{2}$ will likely give annual grasses a competitive advantage in ecosystems with depleted herbaceous species or low resistance to invasion, but not in those with relatively high resilience and resistance (Figure 3D).

Nitrogen deposition may have a fertilization effect in N-limited cold deserts, but the magnitude of the effect depends on the amount of deposition and ecosystem resilience and resistance. Nitrogen deposition is relatively low in cold deserts except for hotspots downwind of metropolitan centers or agricultural operations (Fenn and others 2003). Nitrogen deposition may increase plant growth and primary productivity when saturation levels have 
not been reached and water is not limited (Greaver and others 2012). Grasses typically exhibit a greater response to $\mathrm{N}$ addition than shrubs (Fenn and others 2003), but individual species may respond differently depending on factors such as co-limitation of water and nutrients, plasticity, and tissue nutrient requirements (Drenovsky and Richards 2004). Both perennial and invasive annual $\mathrm{C}_{3}$ grasses exhibit higher growth rates with increased $\mathrm{N}$ availability at both seedling (James and others 2011) and adult life stages (Schwinning and others 2005). Higher growth rates, coupled with early germination and establishment, give invasive annual grasses a competitive advantage over native grass seedlings in both low and high nitrogen environments (James and others 2011), but may have little effect on competition with mature native herbaceous species especially grasses (Blank and Morgan 2012). Thus, low levels of $\mathrm{N}$ deposition may increase the ability of native grasses to compete with annual bromes in ecosystems with relatively high resilience and resistance, but will likely give annuals a competitive advantage in systems with depleted herbaceous species or low resistance. Nitrogen deposition generally stimulates aboveground growth more than belowground and may increase susceptibility to fire due to higher fuel loads and fire severity, and to droughts due to lower root-shoot ratios and reduced water uptake relative to the amount of foliage (Greaver and others 2012).

Interactions among disturbances and stressors may have cumulative effects. Climate change already may be shifting fire regimes outside of the historical range of variability (that is, longer wildfire seasons with more frequent and longer duration wildfires) (Westerling and others 2006). Cold deserts generally have low productivity, and the number of hectares burned often is associated with higher fuels when warm, wet conditions in winter and spring lead to larger burned areas a year or more in the future (Littell and others 2009). Annual grass fire cycles may be promoted by warm, wet winters and a subsequent increase in establishment and growth of invasive winter annuals. These cycles may be exacerbated by rising $\mathrm{CO}_{2}, \mathrm{~N}$ deposition, and increases in human activities that result in soil surface disturbance and invasion corridors. Areas predicted to receive less effective precipitation due to climate warming may have lower climate suitability for cheatgrass. Reduced water availability may limit positive effects of rising $\mathrm{CO}_{2}$, and $\mathrm{N}$ deposition on cheatgrass growth and on vegetation productivity and fuels in general.

\section{How Do Resilience and Resistance to INVASION INTERACT TO DETERMINE THE EfFects of Stress and Disturbance?}

Resilience to disturbance and resistance to invasive species interact to determine ecosystem effects across environmental gradients. In cold desert shrublands, areas of overlap between low ecosystem resilience and resistance to cheatgrass are closely related to observed patterns of cheatgrass invasion and dominance (Figure 3). Salt desert ecosystems have low resilience (Haubensak and others 2009) and low to moderate resistance to cheatgrass depending on effective precipitation. Recent expansion of cheatgrass into marginal salt desert environments has been attributed to favorable establishment years (Meyer and others 2001), rising $\mathrm{CO}_{2}$ levels (Smith and others 1987), and high genetic variability (Ramakrishnan and others 2006). Cheatgrass invasion has increased fine fuels and wildfires are burning in these systems for the first time in recorded history (Haubensak and others 2009).

Wyoming big sagebrush ecosystems also have relatively low resilience and are the least resistant to cheatgrass invasion and dominance of the cold desert ecosystems. These ecosystems have high levels of anthropogenic disturbance due to moderate climates and relatively flat topography. They also have high climate suitability to cheatgrass (Chambers and others 2007). Repeated fire and threshold transitions to annual grass dominance are highest in these ecosystems (Knapp 1996). An unprecedented loss of topsoil and available nutrients from wind erosion is occurring in these systems due to increases in fire size (Hasselquist and others 2011; Sankey and others 2009) and the lack of native herbaceous species to stabilize soils (Hoover and others 2012).

Mountain big sagebrush and mountain big sagebrush/shrub ecosystems have relatively high inherent resilience (Seefeldt and others 2007), but their resistance to cheatgrass is a function of soil temperature (Chambers and others 2007). Consequently, depletion of perennial herbaceous species due to either inappropriate livestock grazing or encroachment of piñon and juniper trees can promote cheatgrass following fire at the warmer but not cooler end of the mountain big sagebrush gradient (Chambers and others 2007).

These patterns of resilience and resistance can be observed at landscape scales following fire and management treatments in sagebrush ecosystems. The effects of repeated fire, seeding, and herbicide treatments were examined over an elevation 
gradient at the Arid Lands Ecology Reserve (ALE) in south-central Washington (Davies and others 2012). Lower elevations were dominated by Wyoming big sagebrush and cheatgrass prior to fire, and invasive annual forbs after fire, seeding, or herbicide treatments. Substantial changes in species composition occurred over time with little sign of recovery to initial conditions. Mid elevations were associated with native perennial bunchgrasses, invasive annual forbs, and a range of native forbs, and exhibited only moderate change following repeated fire and seeding. Higher elevations were associated with a resprouting shrub and native perennial bunchgrasses, and after repeated fire showed little change in species composition and abundance and only slight decreases in cover. Resilience increased along the elevation gradient due to increasing abundance and cover of fire-tolerant native perennials; resistance to invasion increased at higher elevations due to lower climate suitability for cheatgrass and greater competition from the native community.

\section{How CAN WE USE THE CONCEPTS OF RESILIENCE AND RESISTANCE IN A Management Context?}

Researchers and managers alike have emphasized the need to implement management actions that will increase resilience of native ecosystems to stress and disturbance and/or enhance resistance to invasion to prevent crossing thresholds to annual grass dominance (Briske and others 2008; Holling 1996) and an associated increase in fire frequency (Brooks and Chambers 2011). In cold deserts, a suite of different vegetation management treatments are used to reduce woody fuel loads and thus fire severity and extent, decrease competitive suppression of perennial herbaceous species by woody species and cheatgrass, and revegetate degraded or cheatgrass dominated areas with perennial herbaceous species and shrubs. These include various combinations of prescribed fire, mechanical treatment, and herbicide application to decrease sagebrush, piñon, and juniper abundance, herbicide application to control cheatgrass, and seeding of perennial herbaceous species and shrubs to reestablish perennial plant communities (Monson and others 2004; Pyke 2011). Responses to these treatments often vary largely due to inherent differences in resilience and resistance to cheatgrass and other invasive annuals (Miller and others 2013). An understanding of how these differences influence effectiveness of management treatments can be used to determine appropriate management strategies at both site and landscape scales.

State and transition models are a central component of ecological site descriptions that are widely used by managers to illustrate changes in plant communities and associated soil properties, causes of change, and effects of management interventions (Stringham and others 2003; Briske and others 2005; USDA Natural Resources Conservation Service 2013). State and transition models that incorporate resilience and resistance concepts can be used to better illustrate vegetation dynamics and increase management effectiveness (Briske and others 2008). Recent research in cold desert shrublands allows us to construct a conceptual model that shows the alternative vegetation states, transitions among states, and thresholds for warm and dry (mesic/aridic soil temperature/precipitation regime) big sagebrush ecological types with low resilience and resistance as compared to cool and moist (frigid/xeric soil temperature/precipitation regime) mountain big sagebrush ecological types with moderate to high resilience and resistance (Figure 5; Chambers and others unpublished; Davies and others 2012; Miller and others 2013). In cold desert shrublands, resilience to disturbance, and management treatments is strongly influenced by soil temperature/precipitation regimes, generally increases from warm and dry to cool moist regimes, and levels off or declines with cold moist (cryic/xeric soil temperature/precipitation) regimes (Figure 3A). Resistance to cheatgrass and other annual exotics also is influenced by soil temperature/precipitation regimes and is generally lowest in warm and dry regimes (Figure 3B). Disturbances and management treatments that increase resource availability decrease resistance to cheatgrass and other invasive species (Leffler and Ryel 2012). In cool and moist sites with moderate to high resilience and resistance, various management treatments like proper grazing, prescribed fire, mechanical treatments, and herbicide applications can be used to maintain or increase ecological conditions (Figure 5). However, widespread invasion and increasing dominance of cheatgrass and other annual invaders in warmer and drier sites have altered vegetation dynamics resulting in largely irreversible thresholds once the perennial herbaceous species required to promote recovery are depleted. As both resilience and resistance decrease on these sites, the degree of uncertainty increases and management options become increasingly limited. Climate warming may be shifting vegetation dynamics of cooler and moister mountain big sagebrush ecosystems toward those 


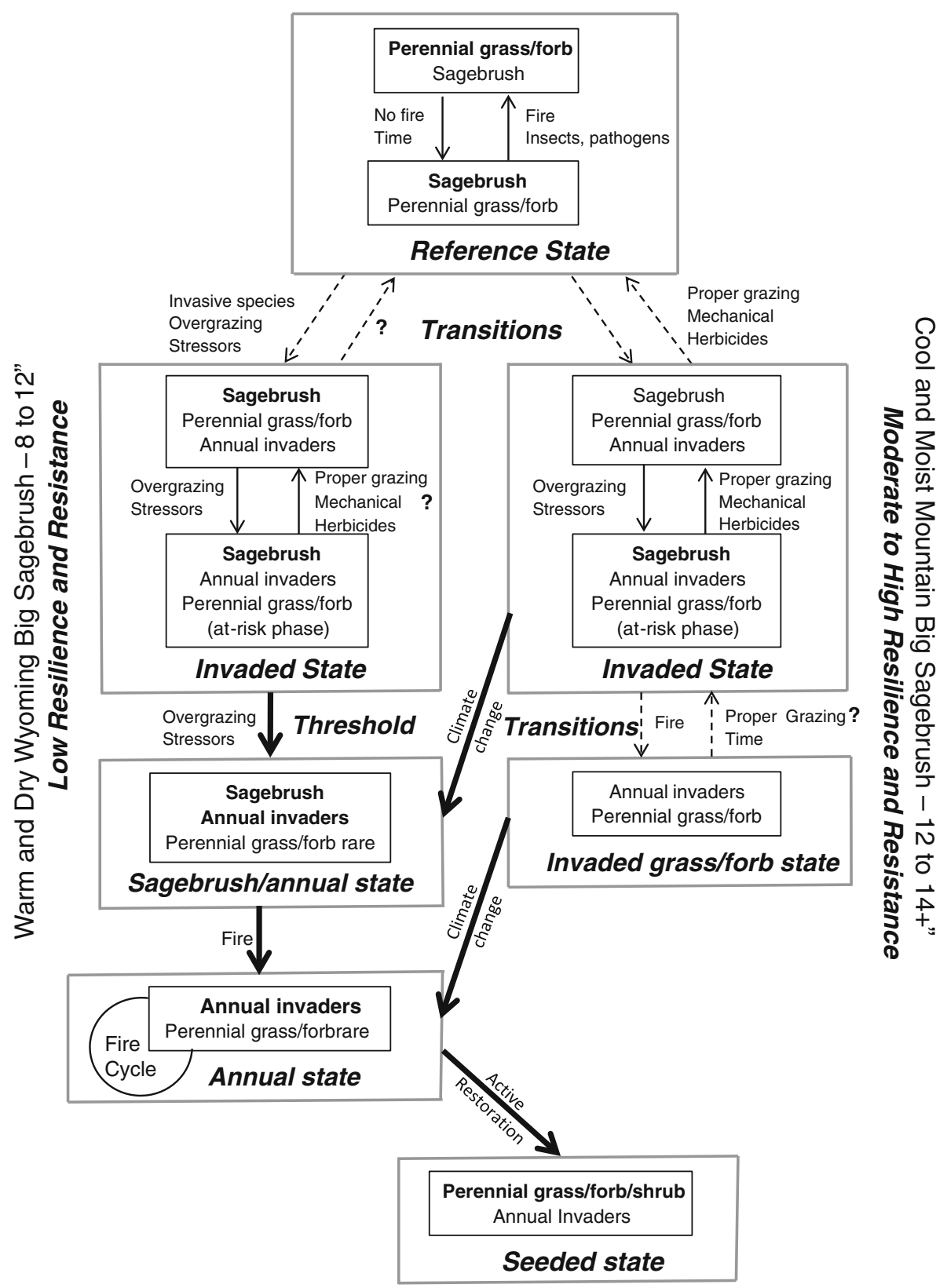

Figure 5. Generalized conceptual model showing the states, transitions, and thresholds for relatively warm and dry Wyoming big sagebrush ecosystems with low resilience and resistance to cheatgrass and cool and moist mountain big sagebrush ecosystems with moderately high resilience and resistance. Reference state: vegetation dynamics are similar for both types. Perennial grass/ forb increases due to disturbances that decrease sagebrush and sagebrush increases with time after disturbance. Invaded state: an invasive seed source, overgrazing, and/or stressors trigger a transition to an invaded state. Perennial grass/forb decreases and both sagebrush and invaders increase with overgrazing and stressors resulting in an at risk phase in both types. Proper grazing, herbicides, or mechanical treatments may restore perennial grass and decrease invaders in relatively cool and moist Wyoming big sage and in mountain big sage types with adequate grass/forb, but return to the reference state is likely only for mountain big sage types. Sagebrush/annual state: in the Wyoming big sagebrush type, overgrazing and stressors trigger a threshold to sagebrush/ annual dominance. Annual state: fire, disturbances, or management treatments that remove sagebrush result in annual dominance. Perennial grass is rare and repeated fire causes further degradation. Seeded state: active restoration results in dominance of perennial grass/forb/shrub. Treatment effectiveness and return to the annual state is related to site conditions, post-treatment weather, and seeding mixture. Invaded grass/forb state: in the mountain big sagebrush type, fire results in a transition to annual invaders and perennial grass/forb. Proper grazing and time may result in return to the invaded state given adequate perennial grass/forb. Increases in climate suitability for cheatgrass and other annual invaders may shift vegetation dynamics of cooler and moister mountain big sagebrush ecosystems toward those of warmer and drier Wyoming big sagebrush ecosystems. 
Table 2. Management Strategies Based on an Understanding of Resilience to Disturbance that Can Be Used to Determine Priority Management Areas at Landscape Scales and Appropriate Management Activities at Site Scales

Protection: maintain or increase resilience and resistance of ecosystems of high conservation value

Focus

- Ecosystem types with low to moderate resilience to fire and resistance to invasive species that are still intact: salt desert shrub and Wyoming big sagebrush

- Ecosystems that provide habitat for threatened and endangered (T\&E) species and can serve as refugia in a warming environment: all ecosystem types

Objective

- Eliminate or minimize current and future stressors

Activities

- Close or actively control wild horse and cattle grazing to prevent loss of perennial native grasses and forbs and allow natural regeneration

- Suppress fire in lower elevation salt desert shrub, sagebrush and wooded shrublands to prevent an invasive annual grassfire cycle

- Control development of road and utility corridors, urban expansion, and solar energy projects to minimize surface disturbance, invasion corridors, and fragmentation

- Increase efforts to detect and eradicate invasive species

Prevention: maintain or increase resilience and resistance of areas with declining ecological conditions

Focus

- Ecosystems with moderate to high resilience and resistance: relatively cool and moist big sagebrush and mountain brush ecosystem types

o Ecosystems that exhibit declining conditions due to cheatgrass invasion and/or piñon and juniper expansion

Objectives

- Reduce fuel loads and decrease the risk of large and/or high severity fire

- Increase abundance of perennial native herbaceous species

- Decrease the longer-term risk of cheatgrass dominance

Activities

- Use mechanical treatments such as mowing or herbicides to reduce shrub dominance and promote a functionally diverse community of shrubs, perennial grasses, and forbs

- Use mechanical treatments like cut and leave or mastication to remove trees, decrease woody fuels, and release native grasses and forbs in big sagebrush ecosystems with relatively low resistance to cheatgrass that are exhibiting piñon and/ or juniper expansion

- Use prescribed fire or mechanical treatments to remove trees, decrease woody fuels, and release native grasses and forbs in cool and moist big sagebrush ecosystems with relatively high resistance to cheatgrass that are exhibiting piñon and/or juniper expansion

- Actively manage post-treatment areas to prevent overgrazing and secondary weeds

Restoration: increase resilience and resistance of disturbed, degraded, or invaded areas

Focus

- Wildfire areas: all ecosystem types

o Ecosystems with low resilience and resistance due to depleted perennial grasses and forbs, high severity fire, and/or high climate suitability to invasive annuals

- Critical habitat for T\&E species: all ecosystem types

- Areas disturbed by recreational activities, road and utility corridors, urban expansion, solar energy projects, and other types of surface disturbances - all ecosystem types

- Assisted migration for species displaced by climate change - all ecosystem types

- Transformative restoration of areas with novel climates where species are established that are climatically suitable but that have not occurred historically - all ecosystem types

Objectives

- Increase soil stability and curtail dust

- Control/suppress cheatgrass and other invasive plants

- Establish a functionally diverse native plant community

Activities

- Use integrated strategies to control/suppress cheatgrass and other annual invaders

- Seed perennial herbaceous and shrub species adapted to local conditions

- Actively manage post-treatment areas to prevent overgrazing and secondary weed invasion 
Table 2. continued

Monitoring and adaptive management: implement comprehensive monitoring to track landscape change and management outcomes and provide the basis for adaptive management

Focus

- Regional environmental gradients to track changes in plant community and other ecosystem attributes and expansion or contraction of species ranges: all ecosystem types

- Pre- and post-treatment areas: all ecosystem types

Objectives

- Understand effects of climate change and other global stressors in cold desert shrublands

- Increase understanding of the effects of management treatments

Activities

- Establish a regional network of monitoring sites that includes major environmental gradients

o Collect data on effects of disturbances like fire and overgrazing (for example, soil erosion, dominant native, and invasive species) and stresses like climate change (for example, phenology, species occurrence) and $\mathrm{N}$ deposition (for example, soil $\mathrm{N}$ levels)

o Include multiple scales, like the landscape, ecological site, and patch, to help explain differential effects of landscape heterogeneity, disturbance history, and land use

- Collect pre- and post-treatment monitoring data for all major land treatments activities

- Use a common data base for all monitoring results (for example, Land Treatment Digital Library; http://greatbasin.wr. usgs.gov/ltdl/)

- Develop monitoring products that track change and provide management implications

- Use a cross-boundary approach that involves all major land owners

of warmer and drier Wyoming big sagebrush ecosystems.

Management options in cold desert shrublands are structured both by the presence and extent of ecosystem types with low resilience and resistance and the fact that many of these ecosystems have crossed abiotic and/or biotic thresholds (Miller and others 2011). An understanding of resilience to disturbance and resistance to invasion and the management options for these ecosystems can be used to develop a strategic, landscape-scale management approach. We suggest four basic strategies-protection, prevention, restoration, and monitoring and adaptive management-that can be used to determine priority management areas and appropriate management actions (Table 2).

Protection focuses on maintaining or increasing the resilience and resistance of ecosystems with high conservation value by eliminating or minimizing current and future stressors (Brooks and Chambers 2011). Protection is a viable strategy for intact communities within ecosystem types that have inherently low resilience and resistance-like salt desert and warmer Wyoming big sagebrush ecosystems. These ecosystems are least responsive to vegetation manipulations and seeding treatments and often are at risk of crossing irreversible thresholds. Protection also is used to manage critical habitat for threatened and endangered species and areas designated as climate change refugia regardless of ecosystem type.
Prevention involves increasing both resilience and resistance of ecosystems that have not crossed thresholds, but that exhibit declining conditions and are at risk of high severity fire and invasion (Miller and others 2013). The focus is on ecosystems with higher resource availability and resilience, such as cooler and moister big sagebrush ecosystems. Management objectives are to improve or maintain ecosystem attributes and processes by reducing woody species dominance and promoting a functionally diverse community of shrubs, perennial grasses, and forbs. This may require mechanical and/or fire treatments, changes in grazing management, and reduction of seed sources from exotic species.

Restoration involves increasing resilience and resistance of disturbed, degraded or invaded areas by reestablishing a diverse, functional plant community. Restoration treatments are most likely to succeed in areas with higher resource availability and low levels of invasion, but integrated management strategies can be used to restore priority areas dominated by cheatgrass and other annual invaders (Monaco and Sheley 2012). Management activities may include using herbicides to control/ suppress cheatgrass and seeding perennial herbaceous and shrub species adapted to local conditions. Future restoration efforts will need to include assisted migration for species displaced by climate change. Transformative restoration in which species are established that are climatically suitable but 
that have not occurred on a given landscape historically may be required in areas with novel climates (Bradley and others 2010).

Monitoring and adaptive management is a critical component that is used to track landscape change and adjust future management. Strategically placing monitoring sites along environmental gradients and repeated measurements of key variables can be used to estimate the effects of disturbances like frequent fire and overgrazing and of stresses like climate change and $\mathrm{N}$ deposition. Evaluating the effectiveness of management actions coupled with strategic monitoring can be used to refine our understanding of resilience and resistance to invasion and construct more accurate STMs that address the appropriate scales. Cross-boundary approaches that include all major landowners, use common databases, and provide the necessary synthesis and management implications can be used to adapt management to the changes occurring in these ecosystems.

\section{ACKNOWLEDGMENTS}

This manuscript was improved by review comments from Jayne Belnap, Cynthia Brown, James McIver, Mike Pellant, Stephen Hart, and two anonymous reviewers and benefited from discussions initiated through the Joint Fire Sciences Program, Sagebrush Treatment Evaluation Project (contribution 92), USDA AFRI REENet Project on Exotic Bromus Grasses in the Western US, and USGS Powell Center Workshop on Integrating Ecological Forecasting Methods to Improve Prioritization of Natural Resource Management: An Invasive Species Example.

\section{REFERENCES}

Abatzoglou JT, Kolden CA. 2011. Climate change in western US deserts: potential for increased wildfire and invasive annual grasses. Range Ecol Manage 64:471-8.

Alexander EB, Mallory JI, Colwell WL. 1993. Soil-elevation relationships on a volcanic plateau in the southern Cascade Range, northern California, USA. Catena 20:113-28.

Allen CR, Gunderson L, Johnson AR. 2005. The use of discontinuities and functional groups to assess relative resilience in complex systems. Ecosystems 8:958-66.

Anderson JE, Inouye RS. 2001. Landscape-scale changes in plant species abundance and biodiversity of a sagebrush steppe over 45 years. Ecol Monogr 71:531-56.

Balch JK, Bradley BA, D’Antonio CM, Gomez-Dans J. 2012. Introduced annual grass increases regional fire activity across the arid western USA (1980-2009). Glob Chang Biol . doi:10. 1111 /gcb.12046.

Beckstead J, Augspurger CK. 2004. An experimental test of resistance to cheatgrass invasion: limiting resources at different life stages. Biol Invasions 6:417-32.
Beisner BE, Haydon DT, Cuddington K. 2003. Alternative stable states in ecology. Front Ecol 1:376-82.

Belnap J. 1995. Surface disturbances: their role in accelerating desertification. Environ Monit Assess 37:39-57.

Blank RR, Allen FL, Young JA. 1996. Influence of simulated burning of soil litter from low sagebrush, squirreltail, cheatgrass, and medusahead sites on water-soluble anions and cations. Inter J Wildland Fire 6:137-43.

Blank RS, Morgan T. 2012. Suppression of Bromus tectorum L. by established perennial grasses: potential mechanisms: part I. Appl Environ Soil Sci. doi:10.1155/2012/632172.

Booth MS, Caldwell MM, Stark JM. 2003. Overlapping resource use in three Great Basin species: implications for community invisibility and vegetation dynamics. J Ecol 91:36-48.

Bradley BA, Blumenthal DM, Wilcove DS, Ziska LH. 2010. Predicting plant invasions in an era of global change. Trends Ecol Evol 25:310-18.

Bradley BA, Mustard JF. 2005. Identifying land cover variability distinct from land cover change: cheatgrass in the Great Basin. Rem Sensing Environ 94:204-13.

Bradley BA, Oppenheimer M, Wilcove DS. 2009. Climate change and plant invasions: restoration opportunities ahead? Glob Chang Biol 15:1511-21.

Briske DD, Fuhlendorf SD, Smeins FE. 2005. State-and-transition models, thresholds, rangeland health: a synthesis of ecological concepts and perspectives. Rangeland Ecol Manage 58:1-10.

Briske DD, Bestelmeyer BT, Stringham TK, Shaver PL. 2008. Recommendations for development of resilience-based stateand-transition models. Rangeland Ecol Manage 61:359-67.

Brooks ML, Chambers JC. 2011. Resistance to invasion and resilience to fire in desert shrublands of North America. Rangeland Ecol Manage 64:431-8.

Brooks ML, D'Antonio CM, Richardson DM, Grace JB, Keeley JE, DiTomaso JM, Hobbs RJ, Pellant M, Pyke D. 2004. Effects of invasive alien plants on fire regimes. Bioscience 54:677-88.

Brooks ML, Minnich RA. 2006. Southeastern deserts bioregion. In: Sugihara NG, van Wagtendonk JW, Shaffer KE, Fites-Kaufman J, Thode AE, Eds. Fire in California's ecosystems. Berkeley: University of California Press. p. 391-414.

Chambers JC, Linnerooth AR. 2001. Restoring riparian meadows currently dominated by Artemisia using alternative state concepts-the establishment component. Appl Veg Sci 4:157-66.

Chambers JC. 2005. Fire related restoration issues in woodland and rangeland ecosystems. In: Taylor, L, Zelnik, J, Cadwallader, S, Hughes, B, Eds. Mixed fire regimes: ecology and management. Symposium proceedings. Association of fire ecologists. MIXC03, Spokane. p. 149-160.

Chambers JC, Roundy BA, Blank RR, Meyer SE, Whittaker A. 2007. What makes Great Basin sagebrush ecosystems invasible by Bromus tectorum? Ecol Monogr 77:117-45.

Chambers JC, Wisdom MJ. 2009. Priority research and management issues for the imperiled Great Basin of the western United States. Rest Ecol 17:707-14.

Chapin FSIII, Torn SE, Tateno M. 1996. Principles of ecosystem sustainability. Am Nat 148:1016-37.

Condon L, Weisberg PL, Chambers JC. 2011 . Abiotic and biotic influences on Bromus tectorum invasion and Artemisia tridentata recovery after fire. Inter J Wildland Fire 20:1-8.

Dahlgren RA, Boettinger JL, Huntington GL, Amundson RG. 1997. Soil development along an elevational transect in the western Sierra Nevada. Geoderma 78:207-36. 
D'Antonio CM, Thomsen M. 2004. Ecological resistance in theory and practice. Weed Tech 18:1572-7.

D'Antonio CM, Vitousek PM. 1992. Biological invasions by exotic grasses, the grass/fire cycle, and global change. Ann Rev Ecol Syst 23:63-87.

Davies GM, Bakker JD, Dettweiler-Robinson E, Dunwiddie PW, Hall SA, Downs J, Evans J. 2012. Trajectories of change in sagebrush-steppe vegetation communities in relation to multiple wildfires. Ecol Appl 22:1562-77.

Davies KF, Harrison S, Safford HD, Viers JH. 2007. Productivity alters the scale dependence of the diversity-invasibility relationship. Ecology 88:1940-7.

Davis MA, Grime JP, Thompson K. 2000. Fluctuating resources in plant communities: a general theory of invasibility. J Ecol 88:528-34.

Dobrowolski JP, Caldwell MM, Richards JR. 1990. Basin hydrology and plant root systems. In: Osmond CB, Pitelka LF, Hidy GM, Eds. Plant biology of the basin and range. Berlin: Springer. p. 243-92.

Drenovsky RE, Richards JH. 2004. Critical N:P values: predicting nutrient deficiencies in desert shrublands. Plant Soil 259:59-69.

Fenn ME, Baron JS, Allen EB, Rueth HM, Nydick KR, Geiser L, Bowman WD, Sickman JO, Meixner T, Johnson DW, Neitlich P. 2003. Ecological effects of nitrogen deposition in the Western United States. Bioscience 53:404-20.

Folke C, Carpenter S, Walker B, Scheffer M, Elmqvist T, Gunderson L, Holling CS. 2004. Regime shifts, resilience, and biodiversity in ecosystem management. Ann Rev Ecol Evol Syst 35:557-81.

Greaver TL, Sullivan TJ, Herrick JD et al. 2012. Ecological effects of nitrogen and sulfur air pollution in the US: what do we know? Front Ecol Environ 10:365-72.

Hasselquist NJ, Germino MJ, Sankey JB, Ingram LJ, Glenn NF. 2011. Aeolian nutrient fluxes following wildfire in sagebrush steppe: implications for soil carbon storage. Biogeosciences Discuss 8:8323-49.

Haubensak K, D'Antonio C, Wilson D. 2009. Effects of fire and environmental variables on plant structure and composition in grazed salt desert shrublands of the Great Basin (USA). J Arid Environ 73:643-50.

Holling CS. 1973. Resilience and stability in ecological systems. Ann Rev Ecol Syst 4:1-23.

Hoover AN, Germino MJ. 2012. A common-garden study of resource-island effects on native and an exotic annual grass after fire. Rangeland Ecol Manage 65:160-70.

Hutchinson GE. 1958. Concluding remarks. Cold spring harbor symposium. Quant Biol 22:415-27.

Jackson ST. 2006. Vegetation, environment, and time: the origination and termination of ecosystems. J Veg Sci 17:549-57.

James JJ, Drenovsky RE, Monaco TA, Rinella MJ. 2011. Managing soil nitrogen to restore annual grass infested plant communities: effective strategy or incomplete framework? Ecol Appl 21:490-502.

Johnson DD, Miller RF. 2006. Structure and development of expanding western juniper woodlands as influenced by two topographic variables. Forest Ecol Manage 229:7-15.

Knapp PA. 1996. Cheatgass (Bromus tectorum) dominance in the Great Basin Desert: history, influences, and persistence to human activities. Glob Environ Chang 6:37-52.

Knick ST, Connelly JW. 2011. Greater sage-grouse: ecology and conservation of a landscape species and its habitats. Studies in Avian Biology, Vol. 38. Berkeley, CA: University of California.
Leffler AJ, Ryel RJ. 2012. Resource pool dynamics: conditions that regulate species interactions and dominance. In: Monaco, TA, Sheley RL, Eds. Invasive plant ecology and management. Linking processes to practice. Cambridge, MA: CAB International. p. 57-78.

Littell JS, McKenzie D, Peterson DL, Westerling AL. 2009. Climate and wildfire area burned in the western U.S. ecoprovinces, 1916-2003. Ecol Appl 19:1003-21.

Merrill KR, Meyer SE, Coleman CE. 2012. Population genetic analysis of Bromus tectorum (Poaceae) indicates recent range expansion may be facilitated by specialist geonotypes. Am J Bot 99:529-37.

Meyer SE, Garvin SC, Beckstead J. 2001. Factors mediating cheatgrass invasion of intact salt desert shrubland. In: McArthur DE, Fairbanks DJ, Eds. Shrubland ecosystem genetics and biodiversity: proceedings. Proc RMRS-P-21. Ogden, UT: U.S. Department of Agriculture, Forest Service, Rocky Mountain Research Station. p. 224-232.

Miller RF, Knick ST, Pyke DA, Meinke CW, Hanser SE, Wisdom MJ, Hild AL. 2011. Characteristics of sagebrush habitats and limitations to long-term conservation. In: Knick ST, Connelly JW, Eds. Greater sage-grouse: ecology and conservation of a landscape species and its habitats. Studies in Avian Biology, Vol. 38. Berkeley, CA: University of California Press. p. 145185.

Miller RF, Chambers JC, Pyke DA, Pierson FB, Williams JC. 2013. A review of fire effects on vegetation and soils in the Great Basin region: response and site characteristics. Gen. Tech. Rep. RMRS-GTR-308. Fort Collins, CO: U.S. Department of Agriculture, Forest Service, Rocky Mountain Research Station. p. 136

Monaco TA, Sheley R. 2012. Invasive plant ecology and management: linking processes to practice (CABI Invasives Series). Oxfordshire: CABI.

Monsen SB, Stevens R, Shaw NL. 2004. Restoring Western Ranges and Wildlands. Gen. Tech. Rep. RMRS-GTR-1136-vol1, 2, and 3. Fort Collins, CO: U.S. Department of Agriculture, Forest Service, Rocky Mountain Research Station. 294+ index.

Neary DG, Klopatek CC, DeBano LF, Ffolliot PF. 1999. Fire effects on belowground sustainability: a review and synthesis. For Ecol Manage 122:51-71.

Nowak RS, Ellsworth DS, Smith SD. 2004. Functional responses of plants to elevated atmospheric $\mathrm{CO}_{2}$ : do photosynthetic and productivity data from FACE experiments support early predictions? New Phyt 162:253-80.

Pausas JG, Bradstock RA. 2007. Fire persistence traits of plants along a productivity and disturbance gradient in Mediterranean shrublands of south-east Australia. Glob Ecol Biogeogr $16: 330-40$.

Peterson G, Allen CR, Holling CS. 1998. Ecological resilience, biodiversity, and scale. Ecosystems 1:6-18.

Polley HW, Morgan JA, Fay PA. 2011. Application of a conceptual framework to interpret variability in rangeland responses to atmospheric $\mathrm{CO}_{2}$ enrichment. J Agr Sci 149:1-14.

Prevey JS, Germino MJ, Huntley NJ, Inouye RS. 2010. Exotic plants increase and native plants decrease with loss of foundation species in sagebrush steppe. Plant Ecol 207:39-51.

Pyke DA. 2011. Restoring and rehabilitating sagebrush habitats. In: Knick ST, Connelly JW, Eds. Greater sage-grouse: ecology and conservation of a landscape species and its habitats. Studies in Avian Biology, Vol. 38. Berkeley, CA: University of California Press. p. 531-548. 
Ramakrishnan AP, Meyer SE, Fairbanks DJ, Coleman CE. 2006. Ecological significance of microsatellite variation in western North American populations of Bromus tectorum. Plant Species Biol 21:61-73.

Reisner MD, Grace JB, Pyke DA, Doescher PS. 2013. Conditions favoring Bromus tectorum dominance of endangered sagebrush steppe ecosystems. J App Ecol. doi:10.1111/1365-2664.12097.

Rejmanek M. 1989. Invasibility of plant communities. In: Drake JA, Di Castri F, Groves RH, Kruger FJ, Mooney HA, Rejmanek M, Williamson MH, Eds. Ecology of biological invasion: a global perspective. New York, NY: Wiley. p. 369-88.

Ryel RJ, Leffler AJ, Ivans C, Peek MS, Caldwell MM. 2010. Functional differences in water-use patterns of contrasting life forms in Great Basin steppelands. Vadose Zone J 9:1-13. doi:10.2136/vzj2010.0022.

Sankey JB, Germino MJ, Glenn NF. 2009. Aeolian sediment transport following wildfire in sagebrush steppe. J Arid Environ 73:912-19.

Schwinning S, Starr BI, Wojcik NJ, Miller ME, Ehleringer JE, Sanford RL Jr. 2005. Effects of nitrogen deposition on an arid grassland in the Colorado Plateau cold desert. Rangeland Ecol Manage 58:565-74.

Seager R, Ting MF, Held I, Kushnir Y et al. 2007. Model projections of an imminent transition to a more arid climate in southwestern North America. Science 316:1181-4.

Seastedt TR, Hobbs RJ, Suding KN. 2008. Management of novel ecosystems: are novel approaches required? Front Ecol Environ 6:547-53.

Seefeldt SS, Germino M, DiCristina K. 2007. Prescribed fires in Artemisia tridentata ssp. vaseyana steppe have minor and transient effects on vegetation cover and composition. Appl Veg Sci 10:249-56.

Smith SD, Strain BR, Sharkey TD. 1987. Effects of $\mathrm{CO}_{2}$ enrichment on four Great Basin grasses. Funct Ecol 1:139-43.

Smith SD, Nowak RS. 1990. Ecophysiology of plants in the Intermountain lowlands. In: Osmond CB, Pitelka LF, Hidy GM, Eds. Plant biology of the basin and range. Berlin: Springer. p. 179-242.
Stringham TK, Krueger WC, Shaver PL. 2003. State and transition modeling: an ecological process approach. J Range Manage 56:106-13.

Stubbs MM, Pyke DA. 2005. Available nitrogen: a time-based study of manipulated resource islands. Plant Soil 270:123-33.

US Department of Commerce, National Oceanic and Atmospheric Administration (NOAA), Global Monitoring Division. 2012. Trends in Atmospheric Carbon Dioxide. http://www. esrl.noaa.gov/gmd/ccgg/trends/.

US Department of Interior. 2010. Endangered and threatened wildlife and plants; 12-month findings for petitions to list the greater sage-grouse as threatened or endangered. Federal Register 75:13910-58.

USDA Natural Resources Conservation Service. 2013. Ecological Site Descriptions. http://www.nrcs.usda.gov/wps/portal/nrcs/ main/national/technical/ecoscience/desc/.

West NE. 1983a. Intermountain salt-desert shrubland. In: West NE, Ed. Temperate deserts and semi-deserts. Amsterdam: Elsevier. p. 375-8.

West NE. 1983b. Great Basin-Colorado Plateau sagebrush semidesert. In: West NE, Ed. Temperate deserts and semi-deserts. Amsterdam: Elsevier. p. 331-50.

West NE, Yorks TP. 2002. Vegetation responses following wildfire on grazed and ungrazed sagebrush semi-desert. J Range Manage 55:171-81.

Westerling AL, Hidalgo HG, Cayan DR, Swetnam TW. 2006. Warming and earlier spring increase U.S. forest wildfire activity. Science 313:940-3.

Wilcox BP, Turnbill L, Young MH, Williams CJ, Ravi S, Syfried MS, Bowling DR, Scott RL, Germino MJ, Caldwell TG, Wainwright J. 2012. Invasion of shrublands by exotic grasses: ecohydrological consequences in cold versus warm deserts. Ecohydrology 5:160-73.

Williams JW, Jackson ST. 2007. Novel climates, no-analog communities, and ecological surprises. Front Ecol Environ $5: 475-82$. 